\title{
Factors that Affect the Sustainability of Literacy Education Program
}

\author{
Safuri Musa \\ Nonformal Education Department, \\ STKIP Siliwangi \\ Cimahi, Indonesia \\ safuri@ymail.com
}

\begin{abstract}
Illiterate people in Bazartete Sub District - Liquica District - Timor Leste are estimated more than 42 percent of the total population of 27,115 people (2015). Many efforts have been taken, such as by involving Fatumasi Community Learning Center (CLC) in implementing literacy education programs. Based on the initial assessment results, there were some problems in implementing literacy education at Fatumasi CLC. By taking case study, the purpose of the study is to describe factors that affect the sustainability of literacy education programs at Fatumasi CLC. Theory bases in the study are the concept of literacy education and community learning center. The study result has shown that factors that affect the sustainability of literacy education programs at Fatumasi CLC - Timor Leste had been; lack of dedication of teachers and education personnels, lack of motivation to learn and aspirations of learners, diversity language in the community, limited learning materials and limited community resources. The study concludes that literacy competencies is fundamental skills that should be mastered by each person to be more developed, independent and welfare, including communities in Timor Leste, especially in Bazartete Sub District.
\end{abstract}

\section{Keywords - literacy education, community learning center}

\section{INTRODUCTION}

Literacy competencies are fundamental skills that should be mastered by each person to be advanced and civilized [1],[4]. Literacy skills are known as reading, writing and basic knowledge [5]. Timor Leste which was colonized by Portugal since 16th century until being independent in 1976 and civil war in 1975 had many illiterate people. When became a part of Indonesia (1976), there have been some efforts to eliminate illiteracy. After Timor Leste has been independent as a country in May 20, 2002, some efforts have kept taking. Especially in Bazartete Sub District, the number of illiterate people in 2015 was $42 \%$ of the total population of 27,115 people.

The government of Timor Leste has kept trying to eliminate illiteracy. Some cooperation has taken with some countries, such as Cuba, Portugal, Brazil, Spain and Indonesia, also the involvement of international boards and NGOs which have given contribution in eliminating illiteracy. Besides, the government of Timor Leste has also involved the participation of community organizations, such as Community Learning Centers. One of them is Fatumasi CLC in Bazartete Sub District - Liquica District. I with the assistance of funds from
UNESCO has taken accompaniment to Fatumasi CLC. One of the research has been a study of the sustainability of the literacy education program. I have faced some challenges in taking accompaniment because the infrastructure had been broken, the electricity, water and food facilities had been limited, as well as culture and customs factors which had been left behind [6].

\section{METHODS}

The study has used qualitative descriptive approach with case study for four months, since August until November 2015. Data has been collected by taking observation, interview and documentation study. During the data collection, I have been participatory involved the activities implemented by Fatumasi CLC

\section{RESULTS AND DISCUSSION}

Factors that affect the sustainability of literacy education programs at Fatumasi CLC; first, lack of dedication of teachers and education personnels. Teachers are the key factor of the success of the literacy learning process, although they have been given adequate incentive, several trainings, curriculum and learning facilities. Education personnels have also given contribution in supporting learning activities, such as administration, financial, learning rooms and learning facilities. If the dedication of teachers and education personnels has been low, the learning process of literacy programs would have been optimum. The lack of dedication has been shown by the less unprepared teachers in taking learning preparation; they haven't prepared learning media for supporting learning topics, they have used monotonous learning methods because they have usually used lecture and question-answer methods, and the assessment of learning progress haven't been taken properly based on the assessment procedures, both the assessment of learning progress and the assessment of final learning [7].

Second, lack of motivation to learn and aspirations of learners. It has been shown by the sparse attendance, the lack of concern and aspiration during the learning process and the lack of independent learning at home or out of scheduled learning process. The condition has made the learning process became less dynamic and monotonous [7]. 
Third, diversity language in the community. In Timor Leste, formal languages are Tetunese and Portuguese. Tetunese is one of dozen mother tongues in Timor Leste. Each District even Sub District has own mother tongue. Besides, Indonesian language is still used in trading and at school for senior high school and university level. English is also used for some expatriate in Timor Leste. Nowadays, the foreigners from China have been increased to take some business in Timor Leste. Community and government of Timor Leste haven't been the settled language to be formal language, to be used in the government, school, relations and trading. The condition is affected the communication in the life of Timor Leste communities, and it is implied in the materials of literacy education [6].

Fourth, limited learning materials which support learning activities. The observation results have shown that reading materials for literacy learners which support the learning process have been very limited in government offices, libraries, book stores and learning groups. Learners have more focused on what teachers have taught, and learning resources to fluent their literacy skills have been so limited [8], [9].

Fifth, limited human resources support, because of economic, culture and social factors. Economic factor has been shown by the lack of per capita income communities. Culture factor has been shown by the community characteristics which haven't been balanced with modern community lifestyle, because they adhere to the customs, not too persistent in taking efforts, and like parties with big budget, not balanced with their poor life. Social factor has been shown by their lack of understanding in organization of modern community life. The factors have affected towards the awareness of the importance of learning literacy program, because they haven't taken benefits of learning literacy program for self-development in economic, culture and social life [10], [5].

\section{CONCLUSIONS}

The conclusion is, literacy competencies is fundamental skills should be mastered by each person to be more developed, independent and welfare, including communities in Timor Leste, especially in Bazartete Sub District. To sustain the literacy education program at the CLC, some hard efforts should be taken, so many obstacles can be handle in reaching the purpose.

\section{REFERENCES}

[1] Richard Desjardins, Determinants of literacy proficiency : a lifelong lifewide learning perspective. International Journal of Educational Research, Volume 39, Issue 3, Pages 205-24, 2003.

[2] Henri Janne, Theorical Foundations of Lifelong Education a Sociological Perspective. Foundations of Lifelong Education, 1976.

[3] RH. Dave, Foundation of Lifelong Education same Methodological Aspects. Foundations of Lifelong Education, 1976.

[4] Richard Desjardins, Determinants of literacy proficiency : a lifelong lifewide learning perspective. International Journal of Educational Research, Volume 39, Issue 3, Pages 205-24, 2003.

[5] Anat Shoshani and Liat Eldor, The informal learning of teacher: Learning climate, job satisfaction and teachers' and student motivation and well-being. International Journal of Educational Research, Volume 79, Pages 52-6, 2016

[6] Margarida Lucas, Isabel Cabrita, and Andriana Ferreira, Pathways to Change: Improving the quality of education in Timor Leste. Procedia Social and Behavior Science. ScienceDirect, 2015.

[7] Max van der Kamp and Emmanuel Boudard, Literacy proficiency of older adults. International Journal of Educational Research, Volume 39, Issue 3, Pages 253-26, 2003.

[8] Gilje, and Ola Erstad, Authenticity, agency and enterprise education studying learning in and out of school. International Journal of Educational Research, 2016.

[9] Sofia Loredana Tudor, Formal-Nonformal - Informal Education. Procedia Social and Behavior Science. ScienceDirect, 2013.

[10] Narong Sompang and Nattaphan Rampai, The Develompemt Model of Knowlode Management to Strengthen Thai ICT Community Learning Center. Procedia Social and Behavior Science. ScienceDirect, 2014. 